DOI: https://doi.org/10.3126/njdrs.v16i0.31572

\title{
Factors Affecting Inclusive Development in Nepal
}

\author{
Ratna Mani Nepal, PhD \\ Faculty member at Central Department of Rural Development \\ Email for correspondence: ratna.nepal@cdrd.tu.edu.np and nepalratnamani@gmail.com
}

\begin{abstract}
The pathways of Nepal's inclusive development date long back. Since the inception of periodic economic development plan in the middle of the fifties, the country has been enduring goals for reforming just and equitable society. In the successive periodic plans, the objectives sharpened further. Yet, the country endorsed inclusive strategies and policies in par with global trends since the tenth plan (2002-2007). In this respect, this paper shortly reviews the concept of inclusive growth and inclusive development and juxtaposes these to elucidate factors causing Nepal's inclusive development. It analyses the country's macro-economic indicators to scrutinize them for their role in ensuring inclusive growth and development. The paper concludes that the country's fluctuating, polarized growth and weakening macro-economic indicators have been posing challenges to the inclusive development.
\end{abstract}

Key words: Inclusive development, Nepal's economy, trade deficit, unemployment, poverty, inequality

\section{Background}

Generally, the new millennium has woken up with substantial changes in development policy outlooks. For some, this shift has been a weapon to fight the ills precipitated by the 'Atlantic liberal democratic tunnel vision'. It is believed that the inability of the 'open market economy' to safeguard social rights and state's activism need to be compensated and the issues of economy's polarization should be addressed.

Pieterse (2019) argued that the wealth concentration and growing dissatisfaction among masses are the results of tunnel vision of the 'Atlantic'. Under the Washington Consesus, the 'Atlantic' imposed the policies of structural adjustment and financial reform in the developing nations. The result eventually became financialization, debt crisis, 'Social Darwinism', and abandoning sectors such as agriculture. The 'con-sensus' in the Washington turned out to be 'di-sensus' in the Kathmandu. Indeed, after less than a decade of implementation of structural adjustment policies, Communist Party of Nepal, Maoist (CPN/M), which waged a decade-long armed revolution, raised among others, the demand of 'de-linking', and has had followers from a wide circle.

A new turn in development studies should be a well-come tune for developing countries. Yet, inclusiveness is equally an agenda of all economies (UNDP, 2019). With the 2007-08 global financial crises, an increasing dissatisfaction towards 'one size fits all' notion of liberal market economy has been surfaced (Picketty, 2014; Pieterse, 2019; Stiglitz, 2013). This orientation is finding in inclusive 
development the strength to address contemporary political economic issues, e.g. poverty, inequality, unemployment, social rights of disadvantaged groups (DAGs) among others.

\section{Concept of Inclusive Development}

Inclusive development pursues strategies to ensure rights of the masses, wealth distribution, social security, and equal access to the public and private services (Sachs, 2004; ADB, 2014; Oxfam, 2011; WB, 2013). It is an indication that political economy of economic development is shifting from the liberal market economy to social democracy. Wealth concentration and inequality are considered as the outcome of liberal policies that were made mandatory after the Washington Consensus. Social democratic policies, however, tend to be distributive. Gupta et. al., (2015) believed that inclusive development is a holistic yet inclusive growth accompanied by the compounded efforts of local, national, and international communities. It is concerned with people, communities, societies, state, and environment and ecology.

Employment generation, poverty reduction, and inequality management have been discussed as the major issues of inclusive development (ADB, 2014; Oxfam, 2011; UN, 2015; UN, 2019). Investment is the precondition to generate jobs. The jobs need to get to the access to the needy. Hence, creating an enabling environment, capability enhancement, and curtailing the 'unfreedoms' as described by Sen (2005) get attention. Addressing poverty and inequality depends upon creation of decent jobs across regions and social strata. According to the World Bank (2008), a developing country needs to invest 25 percent of its gross domestic products (GDP) at the minimum to ensure inclusive development.

State has been described as the prime agency of inclusive development. Yet, the role of productive and dynamic market and organized civil society has not been discarded. The trio's balanced role indicates a coordinated market economy (Pieterse, 2019). The coordinated action turns out to be 'inclusive' when the state leads. Hence, a revision of state-led-development appears in the concept of inclusive development. Nevertheless, achieving inclusive development means pursuing inclusive growth. It is possible in a globalized and democratically inclusive society (Sachs, 2004). Inclusive growth is 'fast, high, and sustainable' (WB, 2008), 'broad based, widely distributed' (UNDP, 2015), 'shared'(UNDP, 2019), 'ensuring access to opportunities and social protection' (ADB, 2014). It ensures inclusive development if a country pursues 5 percent constant rate of GDP growth over the years (WB, 2008). Inclusive growth depends on the effective allocation of resources. In comparison to traditional sectors, new sectors e.g. IT (OECD, 2012) favor it more.

Here the conceptual constellations of inclusive growth imply that it carries some of the elements of the concept 'wealth distribution' discussed during the alternative development movement in the seventies. As argued by the school of dependency, economic growth had been global accumulation since the colonial era. The linear, parochial and lopsided 'econo-centric' development had been criticized by the economist Dudley Seers in the middle of the sixties (Nafziger, 2006). The entitlement approaches e.g. basic needs, integrated rural development practiced after the seventies have not been significantly transferred to the wider sections of the population. So the question of 'distribution' had emerged. Being dormant for almost two decades, it is surfaced with the concept of inclusive growth. 


\section{Inclusive Development in Nepal}

Economically, Nepal is grouped among the 'Least Developed Countries (LDC)' with its per capita income a mere 1,048 US\$ (at nominal GDP/PPP). In terms of achievements in human development (HD index $=0.463$ ), it is ranked 157 th out of 187 countries in the world. The country is trapped in low income and poverty. The people living below the poverty line are 18.7 percent $(\mathrm{MoF}$, 2019). Yet, if poverty line is taken 2 US\$/day in par with South Africa's standard than country would have nearly 40 percent people below the poverty line. Despite these all, Nepal has expected to complete transition to developing-country by 2022 (NPC, 2014). Achieving this desired ambition, the country needs to scrutinize how inclusive is its pace of economic development.

Nepal's quest for inclusive development has been long. Since 1964/65 when the third periodic plan was prepared the country set target to increase the gross domestic product by 19 percent (NPC, 1970). The issues of the distribution of wealth, employment generation, increase investment in infrastructure development, social justice had been incorporated in the third and fourth plans. The concept of 'sustained-economic growth' entered in the fourth plan. The successive plans executed during the panchayat period up to the seventh plan continued the aim, further adding the policies pertaining to local and regional development, decentralization, national and international resource mobilization and poverty reduction (NPC, 1992). However, centralized and conservative political economy of the regime constrained the process to achieve the goal. Since 1964/65 to 1989/90, the average annual growth in GDP was 3.4 percent. In the same period, the per capita growth was NRs. 301 $(0.8 \%)$ at $1974 / 75$ prices. Social sector's performance was such that average life expectancy of Nepali citizen reached to 53 years in 1989/90 from 28 years in 1961 (NPC, 1992).

The Eighth and Ninth Plan prepared after the restoration of multiparty system in the 1990 significantly emphasized poverty reduction. However, social and economic exclusion pertaining to wealth distribution and access to public goods were not properly captured. In the tenth plan (20022007), these issues occupied the major space when Nepal set to pursue inclusive growth. This was the first clear statement that Nepal aims 'inclusive, broad based and sustainable growth'. Here is how the country's development strategy matched in its goal the nature of the growth explained by World Bank, Asian Development Bank and related institutions.

\section{Factors Affecting Nepal's Inclusive Development}

Given the country's economic background, economic, political and social factors seem to be responsible for exclusive development. Explained below are some pertinent macro-economic indicators that have affected inclusive growth and inclusive development in Nepal.

Fluctuating economic growth. During 1981-1990, the country witnessed 4.8 percent GDP growth. It increased slightly to 4.9 percent in the decade 1991-2000 when major adjustment policies were implemented. However, the trend took a downward trend, decreasing to 3.7 percent in 2001-2008, and in the recent decade 2007-2014, it is 4.7 percent $(\mathrm{WB}, 2017)$. The figure is still lower

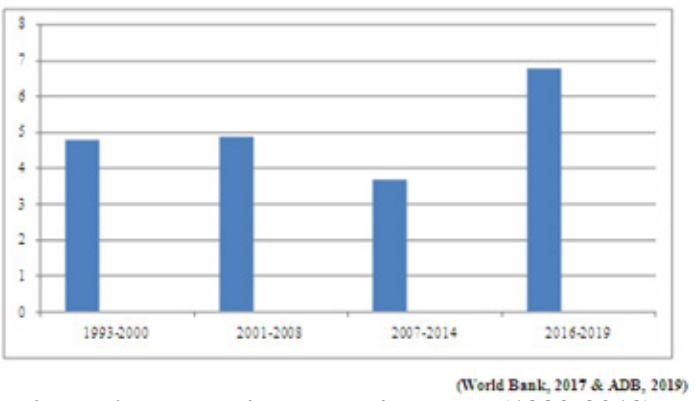

Figure 1. Economic growth in Nepal (1990-2019) 
than the World Bank's average growth standard (5\%) to ensure inclusive growth (Figure 1). Hit by the earthquake April, 2015, the country's economic growth rate frustratingly lowered at 0.5 percent in $2015 / 16$. Nurtured by the reconstruction efforts and so increasing supply, average growth during 2016/17-2018/19 stood at 6.95 percent (ADB, 2019). Though this is a positive sign, the fluctuating growth over the decades show a dismal picture. In order inclusive growth to ensure, smooth performance of the macroeconomic indicators is a precondition.

The largest sector in terms of employment and household dependency is agriculture. However, not only the growth rate but also its contribution to total GDP has decreased by 6.12 percent points since FY 2010/11 (MoF, 2019). It has hit hard to the poor rural farmers and low-income households. Urban middle-class is also affected given the rise of expenditure on daily consumption items. At the rate of 1500 per month, youths in these families are moving abroad in search of employment. It has further resulted in labor deficiency in the agriculture sector. The so-called backbone is now becoming an appendage.

Amid public withdrawal and difficulties in transferring labors from subsistence sector to the modern industrial sector, manufacturing sector is deeply stagnated. The growth in manufacturing sector in 2000 was 1.3 percent, which rose up to 3.6 percent in 2010-13. Now, its contribution to the GDP is around 14 percent, of which around 7 percent is covered by village and cottage industries (MoF, 2019). In a study, Hatlebakk (2008) showed that in 2003, 50 percent non-agricultural jobs were in construction and another 19 percent in manufacturing industries. The study further found that manufacturing sector did not produce full potential of employment because of low public and private investment.

This sector is paying the cost of reform policies pertaining to open market economy adopted after 1990. The country has not been able to improve efficiency, enhance productivity, and generate innovation required to boost up manufacturing sector. Lack of competitiveness in the sector has pushed the country to remain a consumption economy where over six lakh labor force is employed (MoF, 2019). This sector has not able to attract foreign direct investment as it could have been. Institutional and political barriers have been the proximate causes. The capital expenditure as a percentage of GDP is mere 3.9 (NPC 2014), a sharp low figure compared to World Bank's 25 percent investment standard to achieve inclusive growth.

Meanwhile, the growing role of service sector over the economy is a sign of hope. After the peace process in 2006, service sector's contribution to to GDP has been increased by 5.4 points. The sector is thriving due to the massive development and expansion of information and communication technologies such as mobile and internet. Though tourism sector's performance was declining during 2010-2016, it is getting momentum as its contribution to GDP in 2018 is 7.9 percent. Performance of health and education, which belong to the service sector, is desperately slow (ADB, 2019). After 2006, remittances have been dominating the country's economy. The major concern for inclusiveness in the service sector is that it gets national and international shocks such as earthquake of 2015, when the number of tourist arrival decreased due to halt in transportation.

Foreign trade deficit. After the thirty years of democracy and development, the economy's structure is drastically altered. The economic change began with the reformist approach undertaken by the governments in the later period of the Panchayat regime. However, major structural changes were undertaken in the 1990, after the restoration of multi-party democratic system. The protected 
economy was opened up for the foreign enterprises and investors. Not only the public enterprises, but also the health, education, and insurance were privatized. Till date thirty public enterprises have been privatized, of them only 11 are in still operation, 5 are in profit (Kathmandu Post, 2019).

Applied in 1989, Nepal received membership of WTO in 2004. Now, the country liberalized imports of both intermediate and capital goods. Foreign investment in financial markets and some non-tradable sectors were also welcomed. Hence, foreign investment in health and education sectors increased. The reforms also included the agriculture sector as the country became the party to the provision of export subsidies elimination in the sector. With these reforms in the economy, a notable expansion took place. In its reverse effect, the agriculture sector lost productivity, the flow of remittances created domestic demand, which despite internal production depended on global supply. The land locked, underdeveloped country risked increasing trade deficit. For example, export of agricultural products is $215 \mathrm{~m}$ US \$ compared to $1802 \mathrm{~m}$ US\$ import. Total debt service i.e. debt percentage of total export, is 8.5. The trade to GDP ratio is 56 percent in 2017 (WB, 2019). The industrial sector is still highly supported by traditional sectors such as handicrafts.

Exclusive and polarized development. The economic growth and its sources are disproportionately performing in the country. There is regional and sectoral polarization of economic growth. This trend had been significant in the panchayat period (1960-1990). The democratic system too seemed continuing the exclusion despite gross increment in wealth. With the federal republican system in place after 2006, challenge pertaining to the distribution of wealth and opportunities remained.

Of the country's total GDP at the producers' price, NRs. 3464.31 billion, contribution of Bagmati province is few points below the half, whereas Karnali Province is contributing the lowest 3.4 percent in 2018/19. In terms of the net GDP growth, province 5 leads the rank by 1.4 percentage point difference with the Karnali province that ranks lowest (MoF, 2019). The working age population in Bagmati province is 4865 where the number is only 1163 in Karnali province. Deeply rooted regional imbalances add to migration, under-utilization of resources, and social and economic risk. The trend further aggravates the exclusion and polarization.

Government sources show that 20 percent households in the higher economic quintile consume 4.2 times higher compared to the households in the lower quintile (NLSS, 2015/16; UNDP, 2016). Previous year, the ratio was 3.9. Income of the richest 10 percent is three times higher than the poorest 40 percent. Consumption gap by regions is significant. The urban households consume 1.7 times more than rural households.

Development performance also varies by regions (UNDP, 2014). Difference in human development index (HDI) between the highest achiever central development region (HDI $=0.510$ ) and lowest achiever far western development region $(\mathrm{HDI}=0.435)$ is 0.075 points. Among ecological regions, the Hills achieved higher HDI value at 0.520, and the Tarai and Mountain at 0.468 and 0.440 respectively.

The analysis shows that the national wealth is polarized towards the rich, urban centers and country's central region. The result, on the one hand, is lopsided development and, on the other, social and political instability.

Unemployment, poverty, and inequality. Unemployment, poverty and inequality are the burning issues of inclusive development. A country desiring to accomplish a just society needs to 
concern these matters at the earliest. In the country, the share of working age population $(15+$ years $)$ to the total population is 71.5 percent. Among them 55.6 percent are females. Of the 20.7 million potential job seekers, approximately 7.1 million are employed leaving 908 thousand unemployed. Therefore, the unemployment rate in the country is 11.4 percent. Unemployment rate for the females is 13.1 percent, a 2.8 percentage points higher compared to males (CBS, 2019).

A huge disparity in the labor market indicators is seen between females and males. The female employment-to-population (EPR) is 22.9 percent, which is 25.4 percentage points lower than the male EPR. The female labor force participation rate (LFPR) is 26.3 percent compared to the male $(53.8 \%)$. In terms of provinces, disparity is pertinent in the labor market outcomes. According to CBS (2019), Bagmati province reported the lowest unemployment rate (7\%). Yet province 2 has the highest unemployment rate $(20.1 \%)$, which was 8.7 percentage points higher than the national average. Although the gap between urban and rural unemployment rate is minimal, i.e. 10.9 percent vs. 11.6 percent, the disparity in the employment to population ratio is pronounced, i.e. 36.9 percent for urban versus 29.3 percent for rural. As per the Central Bureau of Statics (2019), one in every five people who has jobs in the country is employed in agriculture, the biggest employing industry. Trade industry had the second largest share of employment (17.5\%), followed by construction (13.8\%). The informal sector had a bigger share of 62.2 percent. Close to a quarter of all employed people (23.8\%) are employed in service and sales occupations, followed by elementary occupations with just over 20 percent.

Similally, poverty has been a major cause of the country's backwardness since long (Figure 2). The fist living standard survey report 1995/96 reported 41.8 (equivalent to $42 \%$ ) percent populations below the poverty line. During the second and the third surveys in 2003/04 and

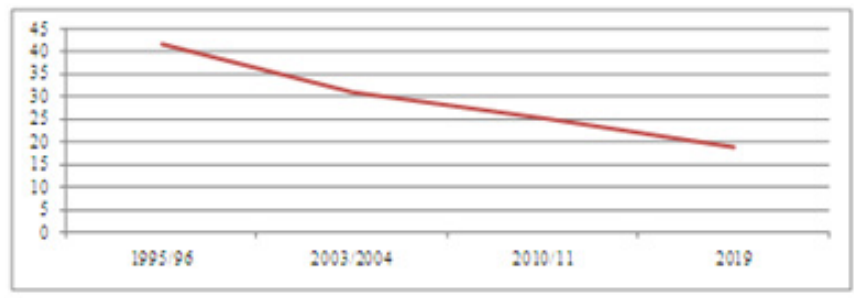

Figure 2. Poverty in Nepal

(CBS, 2019) 2010/11, the figure was 30.9 and 25.2 percent respectively. This shows a significant improvement in the country's poverty scenario. The process is also supported by the decrease in the percentage of urban and rural poor people in the one and half decade (between 1995/96 to 2010/11) (CBS, 2019). With regard to Multidimensional Poverty Index (MPI) (NPC, 2019) (foot note), 28.6 percent population is still 'multi-dimensionally' poor. Under nutrition and lack of any member who has completed five years of schooling are the factors impacting the poverty. In a predominantly agricultural country, 33 percent rural people versus 7 percent urban people are 'multi-dimensionally poor'. Statistics show that Karnali province and province no. 2 have almost 50 percent multi-dimensionally poor. The incidence of multidimensional poverty indicates that the country's development sectors such as health, education, food security, and infrastructure need dire attention and serious review.

Finally, in a transitional economy, wealth distribution could be seemingly unequal. Besides, as Bennett (2005) has maintained, Nepal bears a historical legacy of caste, gender, ethnic groups based on exclusion, which is manifested in wider national and local socio-economic inequalities. More so, right from the beginning income inequality is a rampant issue for inclusive development in Nepal (Figure 
3). Government sources show that 20 percent households in the higher economic quintile consume 4.2 times higher compared to the households in the lower quintile (NLSS, 2016). Previous year, the ratio was 3.9. Income of the richest 10 percent is three times higher than the poorest 40 percent. Consumption gap by regions

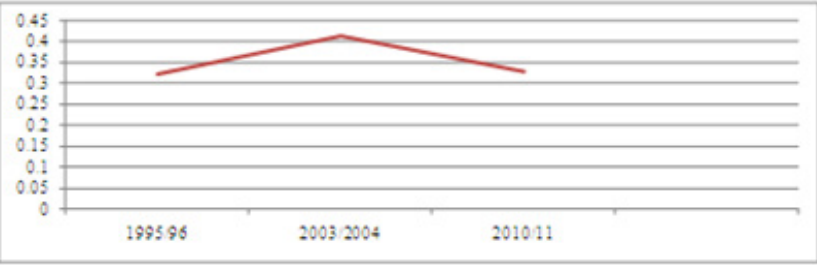

(CBS, 2019)

Figure 3. Income Inequality in Nepal (1996-2011) is significant. The urban households consume 1.7 times more than rural households. Income and wealth inequality show an upward trickling of the growth. The wealth Gini percapita is higher than the income Gini percapita which stands 0.74 . In the agriculture economy, more than half percentage of farmers own less than 0.5 hectors of land, 29 percent have no land at all; whereas 7 percent household own 31 percent land.

According to CBS (2019), the Gini coefficient of income inequality in fiscal years 1995/96 was 0.322 with 0.426 and 0.308 of urban and rural area respectively. In fiscal years 2003/04 the figure increased to 0.414 with simultaneously increment in urban and rural areas (urban $=0.436$, and, rural $=0.349$ ). It indicates that inequality of Nepal is increased as compared to 1995/96 and inequality in urban area is higher than rural area. In fiscal years 2010/11 inequality coefficient was 0.328 with 0.353 and 0.311 of urban and rural area respectively (CBS, 2019). It indicates that inequality of Nepal is decreased as compared to 2003/04 but increased as compared to 1995/96 and inequality in urban is higher than rural area. It is noticeable that over the years the country's gross domestic product has increased by around fifteen times adding wealth in the national account. The urban centers, where the income inequality is higher, produce more opportunities than the rural areas.

\section{Conclusion}

Nepal's quest for inclusive development is long. Indirectly, it started back in the sixties when the country set to attain equitable wealth distribution to ensure people's well being. The periodic development plans adopted by the government continued the aspiration while adopting various strategies and policies. However, in par with global trends, tenth plan introduced the concrete strategies of inclusive development. An overview of the development practice shows that the country's growth performance is skewed and polarized. The economic growth is often fluctuating. It has not met the average 5 percent growth limits over the decades required to meet the inclusive development target. With the adoption of open market policies in the 1990, the country has given passive attention to the agriculture sector. The liberal trade policies in tradable as well as non-tradable goods significantly affected the social and agriculture. It's decreasing contribution to the total GDP means country's imbalance and exclusive development. The secondary sector is still at the state of infancy and stagnated. The economy's growth performance is constrained also by low capital expenditure per annum.

Growth polarization across consumption quintal, regions, and castes is the proximate cause. The deepening gap among various income and social strata means country's underperformance towards inclusive development. 
Given the fluctuating and polarized growth, major economic indicators are deeply affected. Unemployment rate is high. It is disproportionately affecting women and provinces such as Karnali. Absolute poverty is significantly reduced, yet, percentage of 'multi-dimensionally poor' people is around half of the total population. Poverty situation across rural and urban sectors is still higher. As such, income inequality seems to the prime indicator that has deepening effect in inclusive development. Inequality cuts the growth across consumption quintal, regions, and castes. Gender inclusion to contribute inclusive growth is also lopsided.

\section{References}

Acube, M., Shimeles, A., \& Chouchane, A.V. (2012). South Africa's quest for inclusive development. Tunisia: African Development Bank Group.

Asian Development Bank (ADB). (2019). Nepal's economy. Retrieved from, https://www.adb.org/ countries/nepal/economy (Accessed on 8/03/2019).

Asian Development Bank (ADB). (2019). State of poverty in Nepal. Manila. Asian Development Bank.

Asian Development Bank (ADB). (2014). ADB's support for inclusive growth. Manila: Asian Development Bank.

Central Bureau of Statistics (CBS) (2016). Annual household survey, 2015/16. Kathmandu: Government of Nepal and United Nations Development Program.

Central Bureau of Statistics (CBS). (2019). Nepal in figures 2019. Kathmandu: Government of Nepal.

Central Bureau of Statistics (CBS) (2019). Report on the Nepal labour force survey 2017/18. Kathmandu: Government of Nepal.

Gupta, J., Baud, I., Bekkers, R., Bernstein, S., Boas, I., Cornelissen, V., Iguchi, M., Kanie, N., Kim, R. E., Lima, M. B., Obani, P., Schoof, P., Stevens, C., \& Zoomeren, D. V. (2014). Sustainable development goals and inclusive development. Tokyo: UNU-IAS.

Hatelback, M. (2008). Inclusive growth in Nepal. Retrieved from http://issuu.com/cmi-norway/ docs/3068-inclusive-growth-in-nepal/1? $\mathrm{e}=0$

Hau, M. V. (2012). State capacity and inclusive development: new challenges and directions. Manchester: ESID.

Kozuka, E. (2012). Inclusive development: definitions and principles for the post-2015 development agenda. Retrieved from https://jica-ri.jica.go.jp/publication/assets/Chapter\%205.pdf

Ministry of Finance (MoF). (2019). Economic survey 2018/19. Kathmandu: Government of Nepal.

Nafziger, E. W. (2006). From Seers to Sen: The meaning of economic development (WIDER Research Paper, No. 2006/20) Helsinki: The United Nations University World Institute for Development Economics Researc.

Naqvi, S. N. H. (2012). The idea of inclusive growth and development policy. Washington DC: IFPRI. National Planning Commission (NPC) \& Oxford Poverty and Human Development Initiative (2019). Nepal multidimensional poverty index 2018. Kathmandu: Government of Nepal and University of oxford.

National Planning Commission (NPC). (1970). Fourth plan, 1970/75. Kathmandu: Government of Nepal. National Planning Commission (NPC). (1992). Eighth Plan, 1992/1997. Kathmandu: Government of Nepal. 
National Planning Commission (NPC). (2002). Tenth Plan, 2002/2007. Kathmandu: Government of Nepal.

National Planning Commission (NPC). (2014). An approach to the graduation from the least developed country by 2022. Kathmandu: Government of Nepal.

Organization for Economic Cooperation and Development (OECD). (2012). New sources of growth. Retrieved from www.oecd.org/sti/50498841.pdf

Oxford Committee for Famine Relief (OXFAM) \& Humanitarian Accountability Monitoring Initiative (HAMI) (2019). Fighting inequality in Nepal: The road to prosperity. Kathmandu: Oxfam.

Oxford Committee for Famine Relief (OXFAM). (2011). Making growth inclusive: Some lessons from countries and literature. Oxford: Oxfam.

Pieterse, J. N. (2012). Growth and social policies: Towards inclusive development. In Rudolf TraubMerz, (Ed.), Redistribution for growth? Income inequality and economic recovery (pp. 1222). Shanghai: FES.

Pieterse, J. N. (2019). Multipolar globalization: Emerging economies and development. London: Routledge

Sachs, I. (2004). Inclusive development strategy in an era of globalization (ILO Working Paper No. 35). Geneva: ILO.

Sen, A. (2005). Commodities and capabilities (8th ed.). North Holland: Amsterdam.

United Nations Development Program (UNDP). (2014). Nepal human development report, 2014. Kathmandu: UNDP.

United Nations Development Program (UNDP). (2019). Human development report, 2019. Washington DC: UNDP.

United Nations Development Program (UNDP). (2014). Delivering the post-2015 development agenda: opportunities at the national and local levels. Washington DC: UNDP.

World Bank (WB). (2013). World development report, 2013. Washington DC: World Bank Group.

World Bank (WB). (2017). Climbing Higher: Towards a middle income Nepal. Washington DC: Author. Retrieved from, http://documents.worldbank.org/curated/ en/358501495199225866/pdf/115156-CEM-PUBLIC-SAREC-70p-Country-EconomicMemorandum-19-May-2017.pdf.

World Bank (WB). (2019). Nepal's development update, 2019. Washington DC: WB Group. Retrieved form https://www.worldbank.org/en/country/nepal/publication/nepaldevelopmentupdat

World Bank (WB). (2008) The Growth report: strategies for sustained growth and inclusive development. Washington DC: World Bank Group. 